\title{
Constituent Factors and Implications of Work-Life Balance on Female Employees: A Study on the Indian IT industry
}

\author{
Rajesh Veluthan, A. Valarmathi
}

\begin{abstract}
The aim of this review article is to identify the factors affecting work -life balance of female of employees working in Indian IT industry. Today's competitive world, one of the pertinent issues faced by the employees is the lack of balance in work life and family life. Due to various reasons today's female employees in especially IT industry face multifaceted problems in their family life due to lack of balance between job life and family life. The poor match between the job and family life adversely affect the satisfaction level of employees and organizational commitment of them. This study investigates the various factors responsible for the imbalance of job and family life of female employees and gives an insight to the IT companies to review their policy and norms on job and to enhance the employee performance.
\end{abstract}

Keywords: work-life balance, employee performance, female employees, employee satisfaction, organizational commitment.

\section{I.INTRODUCTION}

Indian family is undergoing the changes due to increase in the urbanization and modernization. As a result, women who belong to the all classes entered into the paid occupation. To make focus on the work-life balance of women employee working in IT industry in India, it is known as the important subject in the present time where both men and women at the equal share of the responsibility of learning and earnings for the betterment of their family life. Hence, it is essential to analyze the woman work-life balance between their professional and domestic life. There are various factors that contribute to the work-life conflicts which mainly known as a behaviour factor, time, and stress factor (Greenhaus, et al., 1985). While working in the IT industry, it is essential for the workers to complete the target for the day and as per the desired objective. In respect to this, the working life of the workers in the IT industry makes a hectic schedule so that there is always an issue arises to make a proper balance between their professional life and personal life. To make focus on the women employees working in IT industry, it can be said that women not only need to perform their professional work but they also need to take care of their home, family, and children. As a result, it is a difficult task to manage the work of women professionally and personally.

Revised Manuscript Received on January 03, 2020.

* Correspondence Author

Mr. Rajesh Veluthan*, Research Scholar, R \& D centre, Bharathiar University, Coimbatore.

Dr. A Valarmathi, Director, Vivekananda Institute of Management Studies, Coimbatore.

(C) The Authors. Published by Blue Eyes Intelligence Engineering and Sciences Publication (BEIESP). This is an open access article under the CC BY-NC-ND license (http://creativecommons.org/licenses/by-nc-nd/4.0/)
In respect to this, there are various factors such as recording system, working schedule, social support, workload, Labour Law and policies related to the Employees or women employees, household responsibility, domestic help, family support, partner support and children care issues also affect the job of women so that they will be not able to manage work life in an IT industry. In respect to this, it is essential for IT Industries to develop the fair and sound policies for the payment so that it will be able to manage their work and achieve the work-life balance productivity level effective way.

\section{II.LITERATURE REVIEW}

\subsection{Work-Life Balance: An Imperative Study}

According to Hochschild (1997), to make a good commitment with an organization, it is essential for the firm to promote a work-life balance policies which are compulsory to improve the interest of the governing body. Hyman et al. (2003); Atkinson, et al. (1986), discovered that work-related factors mainly include non-work of the employee's life which mainly create the organizational pressure with lack of facility. All these issues are related and append the type of work autonomy and support given by the organization to the women workers. In respect to this, the work-life balance mainly determines on the basis of three distinct sets of major such as free time, the overlap of work and another dimension of life suggest time is spent with other people. Marcinkus, et al. (2007) point of view, positive Association with the work also support the women to achieve job satisfaction with proper organizational commitment and career achievement. As a result, it was examined that in India, working between men and women is based on experience more work-family and create a family work conflict. The flexibility in independence also experience the working from home facility include weekends in the evening after the work-life balance of working women in IT industry in addition to the quality of life also impact on the home environment. Bachmann (2000) and Schwartz (1994) found that work arrangements such as flexible time, ethnic teleporting is also known as important components that Highly Effective work-life balance of working women in the IT industry. It helps to achieve a better working and non-working activity and assisting the organization to recruit, retain and motivate their workforce effectively. Valk, et al. (2011) also examined in their study that work and family-related factors affect by the women working in IT industry in India and reveals that there are major six major factors that influence such as family influence on life choices, negotiate,
Published By:

\& Sciences Publication

(C) Copyright: All rights reserved.

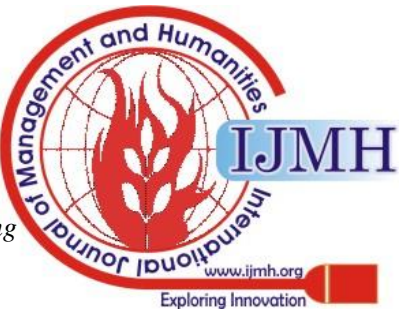


multi-role responsibilities, self and professional, identity, work-life challenges, compacting strategies, organization policies and practices and social reinforcement.

\subsection{Work-Life Balance' Theories}

\subsubsection{Compensation theory}

According to Edwards, et al. (2000); Lambert (1990); Staines (1980), this theory proposed that workers try to compensate for the lack of satisfaction in one domain (work or home) by trying to find more satisfaction in the other. Compensation theory mainly considered as a relationship between the work and family, it occurs when resources are used to fulfill the need of one domain from another domain by adopting the similar buffering effect to the family and work and enrichment. It may be in the form of supplemental and reactive power compensation. To make focus on supplemental compensation, it mainly included an individual who does not receive the reward as per their own domain and speak them from another domain. Relative Converse compensation mainly defines the condition when the undesirable experience is happening in one domain which seeking contracting experience to other individual or another domain effectively.

\subsubsection{Spill-over theory}

According to Edwards, et al. (2000); Illies, et al. (2009); Greenhaus, et al. (1985); Westman (2001); the Spill-over theory proposed that workers carry the emotions, attitudes, skills, and behaviors that they establish at work into their family life. Split over theory is occurred when one domain impact on another domain in the same way and having established boundary between the individuals' family and work spill over take place in both the direction and found to be dependent on the spellings of each roll of pressure.

\subsubsection{The border theory}

As per Ashforth, et al. (2000) Support-Eng (1996a); Zerubavel (1991), each person's roles takes place within a specific domain of life, and these domains are separated by borders that may be physical, temporal, or psychological. Border theory is considered an important political contribution that provides strong starting and deleting the work-life boundaries. It is a fine way by which an individual will be able to create and maintain the boundaries by simplifying and ordering the environment. It mainly includes three types of borders such as temporal, physical and psychological border. To make focus on temporal power boundaries actual time which is related to the completion of the work activity. Physical boundary refers to the actual location in which the work activity takes place and psychological boundaries mainly defined as a perception of the employees associated with the activity of work.

\subsection{Work Antecedents of Work-Life Balance}

According to Dizaho, et al. (2013, June), Pasamar, et al. (2015), it is essential for the organization to provide effective working culture and climate so that employees will be able to manage their working life balance effectively. In respect to this, there are various work antecedents that Highly Effective work-life balance of women employee who works in the IT industry in India. It can be said that the work schedule has the employees to work are which is this differ from the average company start and stop time. The work schedule also has employees to maintain their work and life balance. In respect to this, it is essential for the organization to maintain the organizational structure including with proper fraction for the women employees so that they will be able to manage the burden of the work and responsibility of the family. In addition to this, another factor that highly check balance of Indian IT industry, there are various examples of the IT Industries found that the working of the company or firm are based on the target so that it is essential for the employee to complete the target per day which was determined and delegated as the superior leader. As a result, it creates a negative impact on women working to manage the workload and responsibility of the family children's home. In addition to this, the rewarding system is another that makes a great impact on the work-life balance jobs in IT industry motivation which is in the form of monetary and non-motivation. It may be in the form of salary, hike in growth opportunity, bonus; on the other hand, non-monetary motivation includes an appraisal, promotion and so on. As a result, it was found that is the human will get the effective rewarding system as per the capability level they will get highly motivated with the word and manage their work-life balance by achieving the job satisfaction in an organization effectively. On the other hand, the effective rewarding system adopted by the IT industry is not fair and partial which make negative impact on the attitude and behaviour of the working women so that they will not able to manage the work life and balance their professional and personal life which make negative impact on the growth of an organization. To make focus on social support, it is another factor that Highly Effective female employees working in IT industry to manage work-life balance social support mainly include the customs believes that are adopted and run in a society which is beneficial or not beneficial for the women. As a result, in India, there are various types of caste religion people living together. For example, for Islamic society, there is a limitation for the women to work outside from their home after marriage. They will not get social support so that they will not effect of social support and not manage their work life and personal life effectively. On the other hand, in India, it was also found that women and family support for female employees by providing a positive environment in a home and even organization also under the fair employment policies for the women so that they will be able to work freely without having any kind of hesitation in their mind. Labour laws and employee policies also known as the biggest factors that highly effective and create the relation between the female employees working in the IT industry by affecting their work-life balance. In respect to this, it is essential for the organization to adopt fair policies and employment opportunities for men and women in the IT sector. As a result, it was found that many organisation also try to adopt the fair employment policy such as antidiscrimination law, work health and safety act so that they will be able to provide the same and Secure environment for the working women by reducing the various negative issues that harassment lack of coordination supervisor pod impartial behavior of the senior which make negative impact on their job satisfaction level so that they will not able to manage the work-life balance.

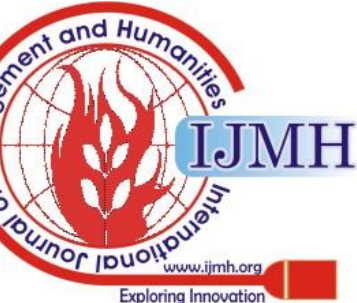




\subsection{Life Antecedents of Work-Life Balance}

According to Saltzstein, et al. (2001), AlHazemi, et al. (2016), Michel, et al. (2011), to make focus on life and different of work-life balance, it mainly include the household responsibility, domestic help, extended family support, partner or parents support, childcare issues that affect the female employees working and affect their worklife balance. It includes the various responsibility of women towards their parent, partner children so that if the women will not able to make a proper balance, some kind of frustration she has faced mentally so that she will not able to manage their work-life balance. In addition to this, domestic help may be in the form of help given by partner while doing the domestic activity such as one-time food preparing by the partner, home cleaning by the partner or a mother. In addition to this, extended activities that can be done by the family members so that it will not make any kind of burden over the working. It may be in the form of partner support or parent support. In addition to this, child issues also affect the employee's client industry. As a result, it was found that who provide the childcare after going to the job to the children is the biggest issue for the working women. In respect to this, there are various child Care Organisation, nursery and family members also provide effective support to that women will be able to manage your work life balance effectively.

\subsection{Organizational WLB Policies/Practices}

\subsubsection{WLB policies/practices' impact on performance and}

\section{job satisfaction}

According to Beauregard, et al. (2009), Arif, et al. (2014), Lazar, et al. (2010), to manage to work-life balance of female employees working in IT industry, there are various policies have been implemented by the organisation that initiates the leave which may be in the form of current leaves that allows employees to take time of care and support for their family or household member. Organisation also provides study or training leave, pulling of leave, entitlement culture and religious break that helps the employee to take the time of their culture and religious reason for a public holiday. In addition to this, the organization also provide paid adoption leave, paternity leave, safety at work driving pregnancy, location break and employee assistance with childcare. Apart from this, the flexible work arrangements also focus in the policy of the organisation in which organization highly focused on job sharing as a part-time working adopt flexitime that helps employee to build an additional part-time work facility, shift work facility, home working, mobile working and gradual retirement that help the employee to gradually reduce the number of working hours and duties over an extended Period of the time. In addition to this, the company also focus on additional work provision such as providing a telephone for personal use, counselling services for employee's health program, exercise facility, equal access to the promotion training and development, parenting of family support program and the location of placement assistance effectively.

\section{III.AIMS AND OBJECTIVES}

- To identify the factors that influence work-life balance within female employees working in the Indian IT industry.

- To identify the work specific factors that influence the work-life balance of female employees in the Indian IT industry.

- To identify the life specific factors/antecedents that influence the work-life balance of female employees in the Indian IT industry.

- To investigate the impact of implementing WLB practices, on female employees' performance and satisfaction level.

- To study the measures to be taken by Indian IT companies to enhance the work-life balance of employees.

\section{IV.FINDINGS AND DISCUSSION}

As per the detailed information, it can be said that there are various constituent factors and implication of work-life balance on female employees working in Indian IT industry. It is essential for the employee to manage their working life and personal life (Lazar, et al., 2010). In respect to this, the study mainly focuses on the working life and organization behavior for the female employees working in IT industry analyze the various theories related to providing work-life balance such as compensation theory, spillover theory, and border theory. In addition to this, the study also focuses on the various working antecedents of work-life balance that highly of affect the females such as schedule work, reward systems and social support (Osoian, et al., 2009). The study also focuses on life in the antecedent of work-life balance such as the house of responsibility, domestic help support from family, parents support and partner support and where is child care issues that highly of the work-life balance of working women in IT industry. The study also examined the various organised balance policies and in the form of flexible type of adoption, remuneration facilities, cares facilities and leaves policies and practices especially the maternity leave for working women's so that they will be able to make a proper balance between their professional life and personal life effectively (Kim, 2014).

\section{V.CONCLUSION}

It can be concluded that it is essential for the employees to manage their work life and professional personal life effectively. The study mainly identifies the factors which influence the work-life balance of employees working in the IT industry in India (Chimote, et al., 2013). It also examines and the work specific factors and life specific factors which influence the work-life balance of female employees working in the Indian IT industry. The study analyzed various theories on work-life balances of female employees. It found that schedule of work, reward system, etc. have significant impact upon the work-life balance as work specific factors. Also, the house responsibility, domestic help from family, parents and partners support, child care issues, etc. are pertinently affecting the female employees as life specific factors.

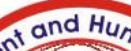


The study also examined the various measures to be taken by Indian IT Company to enhance the work-life balance of employees effectively.

\section{REFERENCES}

1. Al Hazemi, A.A., \& Ali, W. (2016). The notion of work life balance, determining factors, antecedents and consequences: a comprehensive literature survey. International Journal of Academic Research and Reflection, Vol.4No.8, pp. 74-85. http://www.idpublications.org/ijarrvol-4-no-8-2016/

2. Arif, B., \& Farooqi, Y.A. (2014). Impact of work life balance on job satisfaction and organizational commitment among university teachers: A case study of University of Gujrat, Pakistan. Internationa journal of multidisciplinary sciences and engineering, Vol.5No.9, pp. 24-29. http://www.ijmse.org/Volume5/Issue9/paper5.pdf

3. Ashforth, B.E., Kreiner, G.E., \& Fugate, M. (2000). All in a Day's Work: Boundaries of Micro-role Transitions. Academy of Management Review, Vol.25No.3, pp. 472-91. https://asu.pure.elsevier.com/en/publications/all-in-a-days-workboundaries-and-micro-role-transitions

4. Atkinson, J., \& Meager, N. (1986). Changing working patterns. How Companies Achieve Flexibility to Meet New Needs. https://www.researchgate.net/publication/269690425_Changing_Wor king Patterns How Companies Achieve Flexibility to Meet New Needs

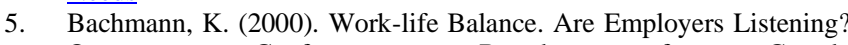
Ottawa: Conference Board of Canada https://wall.oise.utoronto.ca/inequity/2mclean.pdf

6. Beauregard, T.A., \& Henry, L.C. (2009). Making the link between work-life balance practices and organizational performance. Human resource management review, Vol.19No.1, pp. 9-22. http://eprints.lse.ac.uk/25224/

7. Chimote, N.K., \& Srivastava, V.N. (2013). Work-life balance benefits: From the perspective of organizations and employees. IUP Journal of Management Research, Vol.12No.1, pp. 62. https://www.researchgate.net/publication/320076726_Enablers_of_W ork-Life_Balance_An_Insight

8. Dizaho, K.E., \& Othman, F.M. (2013, June). Antecedents of Work Life Balance and Its Impact on Loyalty, Satisfaction and Performance. In A conference paper presented at the Globa Conference on Business, Economics, and Social Research, Kuala Lumpur.

https://www.academia.edu/19278346/ANTECEDENTS OF WORK _LIFE_BALANCE_AND_ITS_IMPACT_ON_LOYALTY_SATISF ACTION AND PERFORMANCE

9. Edwards, J.R., \& Rothbard, N.P. (2000). Mechanisms Linking Work and Family: Clarifying the Relationship between Work and Family Constructs. Academy of Management Review, Vol.25No.1, pp. 17899. https://journals.aom.org/doi/abs/10.5465/amr.2000.2791609

10. Greenhaus, J. H., \& Beutell, N. (1985). Sources of Conflict between Work and Family Roles. Academy of Management Review, Vol.10, pp. 76-88. https://www.jstor.org/stable/258214

11. Hochschild, A. (1997). The time bind. Working USA, Vol.1No.2, pp. 21-29 https://onlinelibrary.wiley.com/doi/abs/10.1111/j.17434580.1997.tb00019.x

12. Hyman, J., Baldry, C., Scholarios, D., \& Bunzel, D. (2003). Work-life imbalance in the new service sector economy. British Journal of Industrial Relations, Vol.41No.2, pp. 215-239 https://www.researchgate.net/publication/4752707 WorkLife_Imbalance_in_Call_Centres_and_Software_Development

13. Illies, R., Wilson, K. S., \& Wagner, D.T. (2009). The Spill-over of Daily Job Satisfaction onto Employees' Family Lives: The Facilitating Roles of Work and Family Integration. Academy of Management Journal, Vol.52No.1, pp. 87-102. https://ink.library.smu.edu.sg/cgi/viewcontent.cgi?article=2743\&cont ext=lkcsb_research

14. Kim, H.K. (2014). Work-life balance and employees' performance: The mediating role of affective commitment. Global Business and Management Research, Vol.6No.1, pp. 37. https://www.questia.com/library/journal/1G1-390091123/work-lifebalance-and-employees-performance-the

15. Lambert, S.J. (1990). Process Linking Work and Family: A Critical Review and Research Agenda. Human Relations, Vol.43, pp. 239-57. http://www.sciepub.com/reference/180509

16. Lazar, I., Osoian, C., \& Ratiu, P. (2010). The role of work-life balance practices in order to improve organizational performance. European Research Studies, Vol.13 No.1, pp. 201. https://www.ersj.eu/repec/ers/papers/10_1_p14.pdf

17. Marcinkus, W.C., Whelan-Berry, K.S., \& Gordon, J.R. (2007). The relationship of social support to the work-family balance and work outcomes of midlife women. Women in Management Review, Vol.22No.2, $\quad$ pp. 86-111 https://www.emeraldinsight.com/doi/abs/10.1108/0964942071073206 $\underline{0}$

18. Michel, J.S., Kotrba, L.M., Mitchelson, J.K., Clark, M.A., \& Baltes, B.B. (2011). Antecedents of work-family conflict: A meta-analytic review. Journal of organizational behavior, Vol.32No.5, pp. 689-725. https://onlinelibrary.wiley.com/doi/abs/10.1002/job.695

19. Nippert-Eng, C. (1996). Home and work. Chicago: University of Chicago Press. https://www.researchgate.net/publication/37687649_Home_and_Wor k_Negotiating_Boundaries_through_Everyday_Life

20. Osoian, C., Lazar, L., \& Ratiu, P. (2009). The benefits of implementing and supporting work-life balance policies in organizations. Managerial Challenges of the Contemporary Society. Proceedings, $\quad$ pp. $333 . \quad$ https://www.managementaims.com/fichiers/publications/174Benito.pdf

21. Pasamar, S., \& Valle, R. (2015). Antecedents of work-life involvement in work-life issues: institutional pressures, efficiency gains or both?. The International Journal of Human Resource Management, Vol.26No.8, $\quad$ pp. 1130-1151. https://www.tandfonline.com/doi/abs/10.1080/09585192.2014.925945

22. Saltzstein, A.L., Ting, Y., \& Saltzstein, G.H. (2001). Work-family balance and job satisfaction: The impact of family-friendly policies on attitudes of federal government employees. Public administration review, Vol.61No.4, $\quad$ pp. 452-467. https://onlinelibrary.wiley.com/doi/abs/10.1111/0033-3352.00049

23. Schwartz, D.B. (1994). An examination of the impact of familyfriendly policies on the glass ceiling http://citeseerx.ist.psu.edu/viewdoc/download?doi=10.1.1.735.8359\& rep=rep1\&type=pdf

24. Staines, G.L., \& O’Connor, P. (1980). Conflicts among Work, Leisure and Family Roles. Monthly Labor Review, Vol.103No.8, pp. 35-39 https://www.cabdirect.org/cabdirect/abstract/19801872499

25. Susi, S., \& Jawaharrani, K. (2011). Work-Life Balance: The key driver of employee engagement. Asian journal of management research, Vol.2No.1, pp. 474-483. http://www.ipublishing.co.in/ajmrvol1no1/voltwo/EIJMRS2041.pdf

26. Valk, R., \& Srinivasan, V. (2011). Work-family balance of Indian women software professionals: A qualitative study. IIMB Management $\quad$ Review, Vol.23No.1, $\quad$ pp. 39-50. https://espace.curtin.edu.au/handle/20.500.11937/47722

27. Westman, M. (2001). Stress \& Strain Cross-over. Human Relations, Vol.54No.6, pp.
https://journals.sagepub.com/doi/10.1177/0018726701546002

28. Zerubavel, E. (1991). The Fine Line. New York: Free Press https://www.worldcat.org/title/fine-line-making-distinctions-ineveryday-life/oclc/23940201

\section{AUTHOR'S PRFILE}

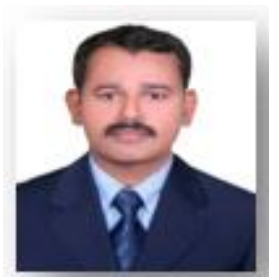

Mr. Rajesh Veluthan, is having 15 years of teaching experience in abroad as well as in India. Currently he is working as faculty in business studies department of Ibri College of Technology under government of Oman. He is pursuing his $\mathrm{PhD}$ in Bharathiar University, Coimbatore now. Earlier he was working in UAE (United Arab Emirates) for 5 years in Birla Institute of Technology International Centre as faculty in Management Studies. He completed his MBA in India in 2000 with the specialization of Marketing and Human Resource. He also completed LLB with excellent academic record. He has also done his MSc. Psychology degree from India. He has attended many seminars, conferences and workshops both in India and abroad.

Published By:

Blue Eyes Intelligence Engineering \& Sciences Publication

(C) Copyright: All rights reserved. 


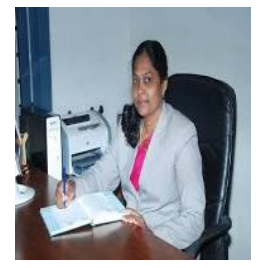

Dr. A. Valarmathi, Director, Vivekananda Institute of Management Studies started her career in industries in an export oriented company. She obtained her Doctoral degree from Mother Teresa Women's University, Kodaikanal. She has completed her M.Phil. from Madurai Kamaraj University. She has 17 Years of experience in teaching and industry and has 10 Years of research experience. She has guided 11 M.Phil scholars and is presently guiding 4 Ph.D. scholars in the area of Marketing and Finance in various Universities like Bharathiar University, Anna University, Karpagam University, Tamilnadu Open University and Periyar University. She has presented and published research articles in 15 International and National conferences and 27 publications in refereed Journals. She has published four books: "Impact of Advertisement on Jewel Purchase Decision", "Accounting for Management", "Written Communication" and "Information Management". She is also a reviewer for Inderscience Publishers Journal, International Journal of Internet Marketing and Advertising and Southern Management Association Journal. She is an active member of the Coimbatore Management Association. She has received the CMA-GRD best MANAGEMENT FACULTY AWARD in 2012. Her areas of interests are Consumer behavior, Financial management, Advertisement and Sales management and Accounting for management. She is the proud alumnus of Indian Institute of Management, Indore.

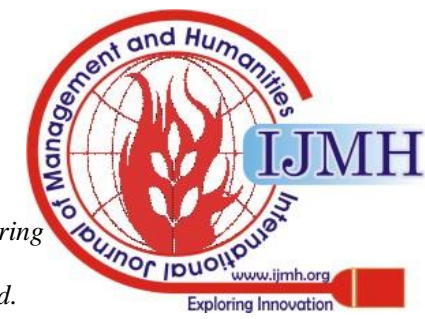

